\title{
教育講演
}

\section{6. 心不全の病態と内科的治療}

\section{吉村 道博}

Key words：ナトリウム利尿ペプチド, レニン・アンジオテンシン・アルドステロン系, 収縮不全, 拡 張不全

はじめに

心不全の病態は基礎疾患や重症度の違いによ り複雑な様相を呈しており，その分類の仕方も 様々である。一般的に心不全の病態は急性と慢 性に分けて議論することが多く，ガイドライン 上もそのように分類されていることから本稿で もそれに従い解説する ${ }^{1,2)}$. しかし多くの場合, お互いは密接に関連している.

急性心不全は, 心臓の器質的・機能的異常に より急速に心ポンプ機能が低下し, 主要臓器へ の灌流不全やうっ血に基づく症状や徵候が急性 に出現した状態である。一方で, 慢性心不全は, 慢性のポンプ失調により肺と体静脈系のうっ血 や組織の低灌流が継続し，日常生活に支障をき たした病態である。しかし, 代償機転の破綻に より病態が急性増悪し, 増悪を繰り返すとさら に悪循環が進行し，急性心不全の病態に陥る。

本稿では, 心不全の病態と内科的治療に関す
る最近の考え方を解説するが, 血行動態的な面 のみならずそれに伴う内分泌学的な変化につい ても解説を加える.

\section{1. 心不全の基本的な病態 : 内分泌学的側 面を含めて}

心不全の病態は, 長年, 血行動態の面から議 論され，重要な知見が数多く残されている。一 方で, 近年はそれに加え心不全時に変化する神 経体液性因子の側面からも心不全の病態を考え る事が多くなってきている3)(図 1).

心拍出量の低下に伴い腎血流が低下し, それ によりレニン・アンジオテンシン・アルドステ ロン（renin-angiotensin aldosterone : RAA）系 などの神経体液性因子が活性化される。 アンジ オテンシンIIの産生の克進, また動脈, 心肺圧受 容体を介した交感神経活動も充進して心拍出量 と血圧を維持しょうとする。ささらにはエンドセ リンなどの血管収縮因子も活性化する。 RAA

東京慈恵会医科大学内科学講座循環器内科

110th Scientific Meeting of the Japanese Society of Internal Medicine : Educational lecture : 6. Pathophysiology of heart failure and medical treatment.

Michihiro Yoshimura : Division of Cardiology, Department of Internal Medicine, The Jikei University School of Medicine, Japan.

本講演は，平成 25 年 4 月 12 日（金）東京都・東京国際フォーラムにて行われた. 


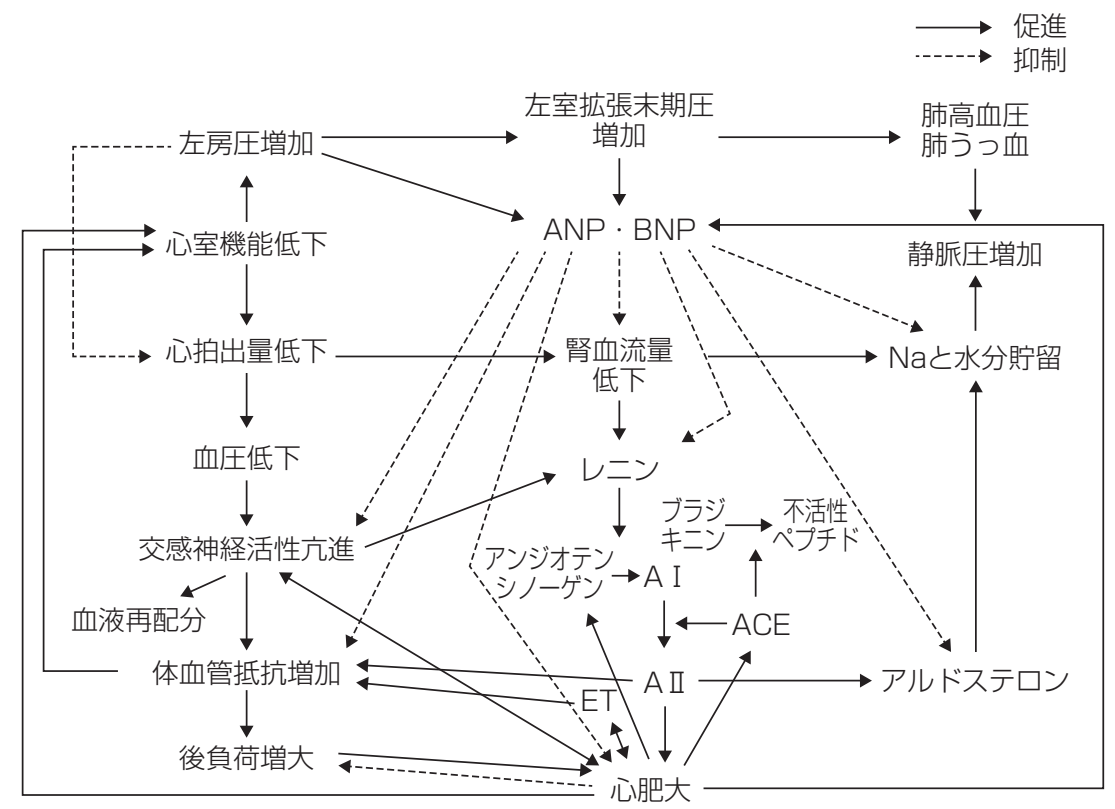

図 1. 左心不全の病態生理 : ANP, BNPを中心に（文献 3 より）

系や交感神経系などの立進は，昇圧やナトリウ ム・体液貯留, または心収縮力の増強と心拍数 を上げ，重要臟器への血流を保持することに役 立つ。それにより血行動態が維持できて比較的 安定している場合は代償期ととらえることがで きるが，これらのホルモンの活性化は多くの場 合, 過剩に働いている. 慢性化すると代償が破 綻して病態悪化の連鎖がはじまり，非代償期へ と陷る。

交感神経系やRAA系などのホルモン群に対抗 するものとしてA型 (または心房性)ナトリウム 利尿ペプチド（A-type or atrial natriuretic peptide：ANP）やB型（または脳性）ナトリウム利 尿ペプチド（B-type or brain natriuretic peptide：BNP）がある。心不全における血漿ANP またはBNP濃度の著しい上昇をみるとそれらが 如何に大きな役割を果たしているかが推察でき るであろう。現在では, 主に心室から分泌され るBNP (またはNT-proBNP) が心不全の生化学 的な診断法として広く普及している ${ }^{2,4)}$.

以上の様に, 心不全は心機能の低下に伴い神
経体液性因子の活性化が深く関与した全身の症 候群ととらえる事ができる.

\section{2. 急性心不全の病態と治療}

急性心不全には $6 \supset 0$ 病態があると言われて いる. (1)急性非代償性心不全, (2)高血圧性急性 心不全, (3)急性肺水腫, (4)心原性ショック：(1) 低心拍出量症候群 (2) 重症心原性ショック, 5 高拍出性心不全, 6急性右心不全である.ただ し，それぞれが独立した概念ではなく，共通領 域が交絡している。いずれの病態においても, 可能な限り, CCUやICUに収容し, NYHA (New York Heart Association) 分類, Killip分類, NohriaStevensonプロファイル, さらに必要な場合には Swan-Ganzカテーテルによる血行動態評価により 重症度評価（Forrester分類）を行い，それらに 基づいた治療法の選択を行う ${ }^{5 \sim 8)}$ (図 2，3）. 同時 に基礎疾患を把握し，治療を直ちに開始する。

うっ血所見がある患者では, 肺うっ血, 体うっ 血, あるいはその両者の合併の有無を診断する. 
NYHA (New York Heart Association) 分類

I 度 心疾患はあるが身体活動に制限はない，日常的な身体活動では著しい疲労，動悸，呼吸困難あるいは狭心痛 を生じない。

【度 軽度の身体活動の制限がある。安静時には無症状，日常的な身体活動で疲労，動悸，呼吸困難あるいは狭心 痛を生じる。

I $\mathrm{s}$ 度 身体活動に軽度制限のある場合

Im度 身体活動に中等度制限のある場合

皿度 高度な身体活動の制限がある. 安静時には無症状. 日常的な身体活動以下の労作で疲労, 動悸, 呼吸困難あ るいは狭心痛を生じる.

IV度心疾患のためいかなる身体活動も制限される。，心不全症状や狭心痛が安静時にも存在する. わずかな労作でこれらの症状は増悪する。

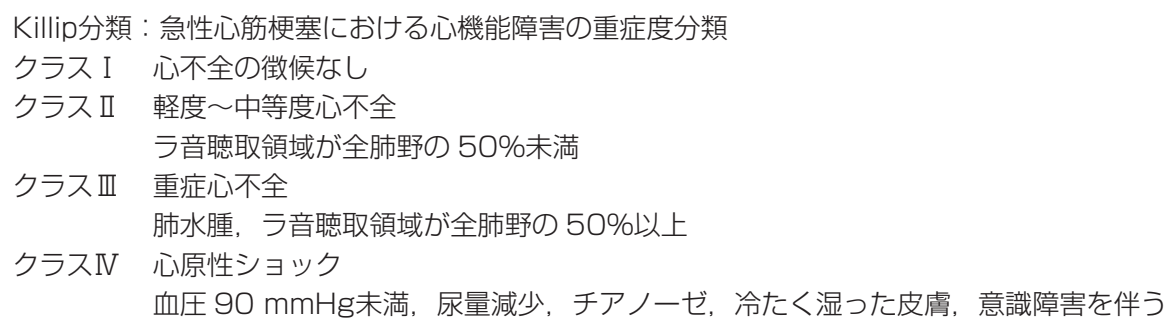

図 2. 心不全の分類（文献 1 より）

Forresterの分類

心係数 $\left(l / \mathrm{min} / \mathrm{m}^{2}\right)$

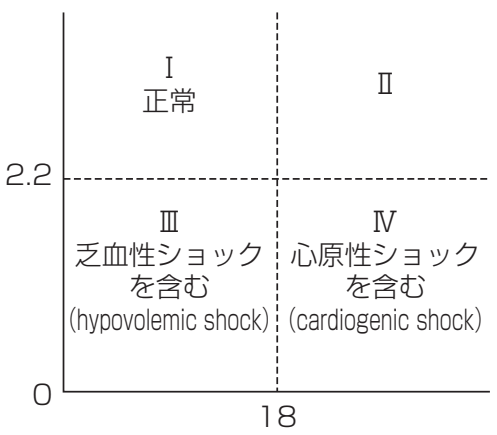

肺動脈楔入圧 $(\mathrm{mmHg})$
Nohria-Stevensonの分類

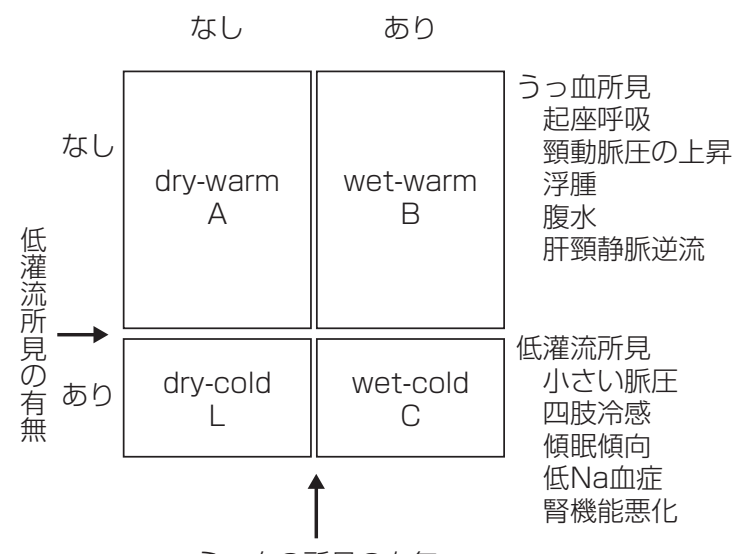

うっ血の所見の有無

図 3. 心不全の分類（続き）(文献 1より)

前者の場合は血管拡張薬を主に使用し, 後者の 場合は利尿薬を中心とした治療を行う。末梢循 環不全の所見がある低血圧(おおよそ $90 \mathrm{mmHg}$ 未満）の症例ではカテコラミン薬の静脈内投与 が必要なことが多い. 酸素投与や非侵襲的陽圧 換気療法 (noninvasive positive pressure ventilation：NPPV)による呼吸管理に次いで, ニトロ
グリセリン舌下や硝酸イソソルビドスプレーの 使用は初期介入として迅速で簡便な良い治療で ある，狭心症発作の寛解のみならず，急性心不 全における肺うっ血・肺水腫の軽減（血圧低下 がない場合）にも有効である，最近，急性心不 全の薬物療法として, 合成ヒトANP製剤である カルペリチドが汎用されている. カルペリチド 
は, 血管拡張作用, ナトリウム利尿作用, 交感 神経系やRAA系の抑制作用などがあり, 血行動 態の改善のみならず藏器保護効果があるとされ ている. 特に心臓や腎臓保護効果が期待されて いる. 目に見えて利尿がつかなくとも臓器保護 という観点からの使用が浸透しつつある. バソ プレシン拮抗薬であるトルバプタムは, 国内で は心不全の適応があるが, もともと海外では抗 利尿ホルモン不適合分泌症候群 (syndrome of inappropriate antidiuretic hormone secretion : SIADH）の薬である.つまり, 低ナトリウム血 症を合併する場合に効果があると考えて良い. 利尿作用が強すぎてかえって脱水にならないよ うに注意が必要である。

治療抵抗性の難治例では, 気管内挿管による 呼吸管理, 限外滤過療法 (extracorporeal ultrafiltration method : ECUM), 持続性血液濾過透析 (continuous hemodiafiltration: CHDF), 大動脈 内バルーンパンピング (intra-aortic balloon pumping : IABP), 経皮的心肺補助装置 (percutaneous cardio pulmonary support: PCPS), 心 室補助装置 (ventricular assist system：VAS)な どが動員される，ただし，VASなどに代表され るように外科的な高度の手技を必要とする治療 法は国内の殆どの施設でまだ行う事は難しいで あろう。現実的には症例毎にそれぞれの病院の 特性に合わせた形で最大限の内科的な治療が基 本であり, 本人や家族と相談の上, 必要な場合 は移送も検討する.

\section{3. 慢性心不全の治療 : 心不全のステージ 別にみた薬物治療}

図 4 に心不全のステージ別にみた薬物治療を 示す2).いずれのステージにおいても強心薬とい うよりは臓器保護の考え方が以前に比べて明確 になっている，その代表が, ACE阻害薬, 抗ア ルドステロン薬, $\beta$ 遮断薬であり, 副作用に注意 しつつも積極的な使用が望まれる.
・ステージA（危険因子を有するが，心機能障 害がない)

高血圧, 耐糖能異常, 脂質異常症, 喫煙等の 危険因子を有する場合には, それぞれのガイド ラインに従ってその是正および治療を行う. 特 に, ステージAから積極的にACE阻害薬を開始 する．既に冠動脈疾患を発症している場合には ACE阻害薬はその二次予防に有用である. ACE 阻害薬に対する忍容性にそしい場合にはARB を使用する. カルシウム拮抗薬は心不全ではあ まり使われることはないが, ステージ Aにおいて は高血圧や虚血性心疾患の場合によく使われ， 冠攣縮を合併している場合は特に推奨される.

\section{・ステージB（無症状の左室収縮機能不全）}

まず, ACE阻害薬が適応となる。ACE阻害薬 の投与が副作用等で不可能な症例では, ARB を投与する. 心筋梗塞後の左室収縮機能不全で あれば $\beta$ 遮断薬の導入も考慮する.心房細動によ る頻脈を伴う症例ではジギタリスを用いること もある。

\section{・ステージC（症候性心不全）}

NYHA II度 : ACE阻害薬に加えて $\beta$ 遮断薬導入 を行う. $\beta$ 遮断薬は心不全治療には無くてはなら ない薬物であるが, その投与量に関しては注意 が必要である。必要以上を投与すると心不全は かえって悪化する事があり, 重症例は専門医に 相談する方が良い.また, ACE阻害薬や $\beta$ 遮断薬 を使う場合, 血中のBNP(またはNT-proBNP)濃 度を測定しておくと心不全管理に有用であろう。

肺うっ血所見や全身浮腫等体液貯留による症 状が明らかである場合には, ループ利尿薬, サ イアザイド系利尿薬を用いる. 洞調律で重症心 室性不整脈を伴わない非虚血性心筋症には, 低 用量ジゴキシンの使用を考慮する。

NYHA III度 : NYHAII度と同様に, ACE阻害 薬, $\beta$ 遮断薬, ループ利尿薬, サイアザイド系利 尿薬，ジゴキシンを用いる。 また，スピロノラ クトンを追加する. 昨今, スピロノラクトンや エプレレノンに関しては（国内ではエプレレ） 


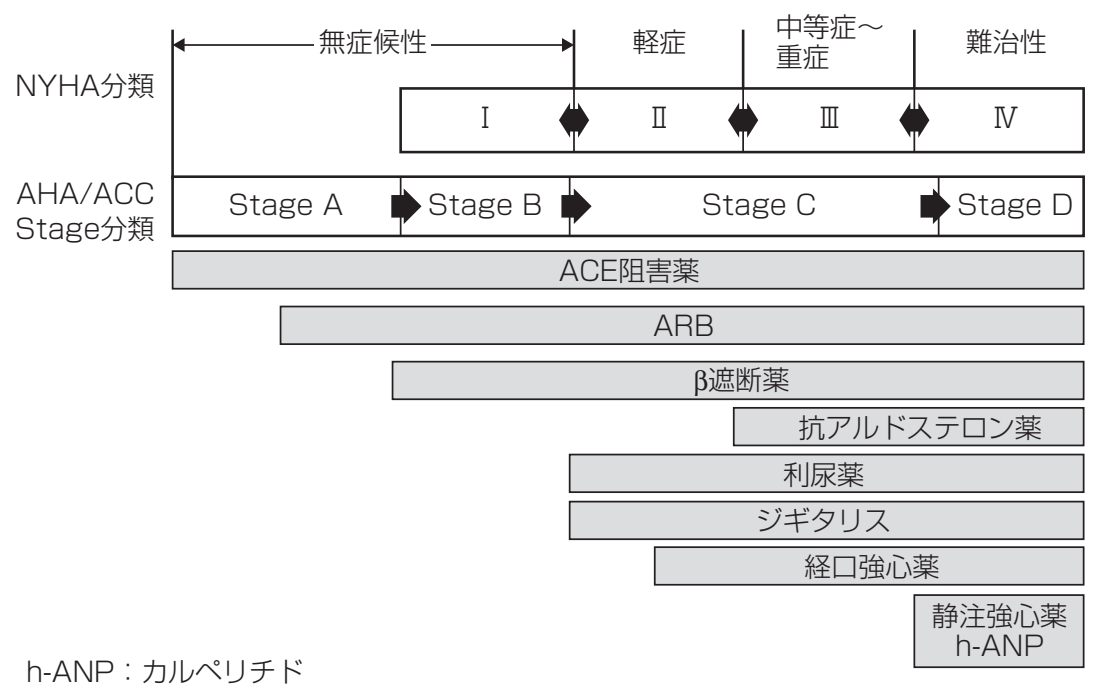

図 4. 心不全の重症度からみた薬物治療指針（文献 2 より）

ンの適応は高血圧のみ), 心不全の大規模臨床試 験でさまざまな優れた結果が報告されており， 以前にも増してその意義が注目されている。一 方で，腎機能低下例や糖尿病例においては高力 リウム血症に注意が必要である.

NYHA IV度：入院治療が基本である. カテコ ラミン製歳，フォスフォジエステラーゼ(PDE) III阻害薬, 利尿薬, カルペリチド等の非経口投 与を行い, 状態の安定化を図る。状態の安定が 得られたならば，ACE阻害薬，スピロノラクト ンを含む利尿薬，ジギタリス等の経口心不全治 療薬へ切り替えていく.さらに $\beta$ 遮断薬導入を試 みるが, $\beta$ 遮断薬に関しては前述の通り投与量に は十分な注意が必要である。

\section{・ステージD（治療抵抗性心不全）}

体液管理と薬物治療が適正であるかを再度見 直す．心臓移植の適応について検討することも ありうるであろう．積極的治療によっても予後 改善が期待されない場合は, 本人や家族の同意 のもとで苦痛の解除を主眼とする末期医療ケア を行うこともあるが, 慎重な判断と対応が必要 である。

\section{4. 拡張不全について}

心不全の出現には，左室収縮機能障害となら び左室拡張機能障害が大きく関与している. 最 近では, 左室収縮性が低下した心不全 (heart failure with reduced ejection fraction : HFrEF) お よび左室収縮性が保持された心不全（heart failure with preserved ejection fraction : HFpEF) に分類して議論されることが多くなり, 収縮不全のみならず拡張不全の重要性に注目が 集まっている ${ }^{9,10)}$.

拡張機能障害を主たる病態とする心不全は, 自覚症状が強く，時に治療抵抗性である，我々 の最近の研究でも急性心不全治療に伴う血漿BNP 濃度の変動パターンから拡張不全が強い例ほど 治療抵抗性であることが分かった ${ }^{11)}$. 拡張機能障 害の原因は様々であり治療方針も一定ではない. 高齢者や女性の割合が多く，高血圧，冠動脈疾 患, 心房細動, 糖尿病, 慢性腎臓病 $(\mathrm{CKD})$, 脳 血管障害などの併存疾患を認めるケースが少な からず存在しており，そのことも治療の難しさ を生じさせている. 


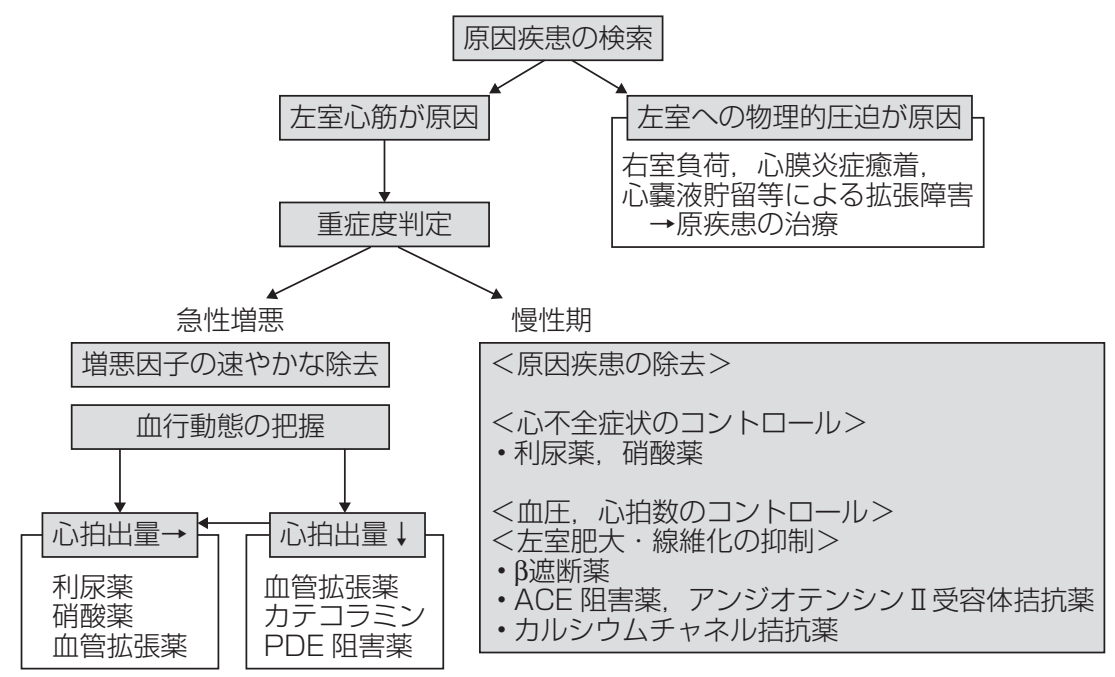

図 5. 拡張不全の治療アルゴリズム（文献 2 より）

拡張機能障害に対する治療アルゴリズムを図 5 に示す2). 拡張不全による急性増悪期の主症状 は, 左房圧上昇による肺うっ血と, 低心拍出症 状である.どちらの症状がより優位かを的確に 把握する必要がある。肺うっ血症状が強く, 心 拍出量が保たれている場合には, 利尿薬, 硝酸 薬が有効である。しかし, 拡張不全では収縮不 全以上に前負荷軽減薬にて容易に心拍出量の低 下を来たすため, 投与量には十分な注意が必要 である，肺うっ血が強く，かつ低心拍出を呈す る場合は, 後負荷を軽減し, 有効心拍出量を増 やす必要がある. ACE阻害薬（またはARB）に よる後負荷軽減とともに, カテコラミン, PDE 阻害薬を併用することもある. カテコラミン, PDE阻害薬は軽度低下している収縮機能を改善 するだけでなく，拡張能も一過性に改善すると 考えられている.ただし, 脈拍・不整脈の増加 には注意すべきである。もちろん, 拡張障害の 増悪因子が明らかであり, 除去可能な場合は当 然ながらそれを取り除くことが必要である（心 タンポナーデなど).

慢性期では, 原因疾患の除去, 心不全症状の コントロール, 左室肥大・線維化の抑制, 脈拍 数のコントロールが重要である. 自覚症状の軽
減には, 心拍出量を過度に減少させることなく, 上昇した左房圧を低下させる必要がある。した がって, 利尿薬, 硝酸薬は有効であるが, 急性 増悪期の治療と同様, 低用量から開始し, 低血 圧・低心拍出症状を慎重に監視すべきである. 心筋が原因である拡張不全の主病態は, 左室肥 大・線維化と考えられており，それらを抑制・ 退縮させる薬凨が有効であろう。近年, RAA 系や交感神経系が左室肥大・線維化に重要な役 割を果たしているという知見が蓄積され, ACE 阻害薬, ARB, $\beta$ 遮断薬への拡張不全予防・治療 効果が期待されていた. しかし，未だ明確な解 答は得られていない. 今後, 抗アルドステロン 薬の効果に期待が集まっており, 大規模臨床試 験が進行中である.

\section{まとめ}

心不全は, 心機能の低下により末梢循環不全 やうっ血を来す病態であるが，そこには数多く の神経体液性因子が関与している。特にRAA 系, 交感神経系は循環維持に役立っているが, それらの過剩な活性化はかえって心不全の病態 を進めている.それに対抗して, 心臓から ANP, 
BNPが分泌され，ホルモンバランスを取ろうと しているが，前者に対しては不十分である．そ こで, この現象を応用する形で血漿BNP濃度測 定が心不全の診断法に, そして合成ヒトANP (カルペリチド)の静脈内投与が急性心不全の治 療法として世界に先駆けて日本で確立された。

急性心不全においては, 救命の観点から迅速 な初期対応が望まれる. 特に血行動態の改善に 重きが置かれ，うっ血がある場合には血管拡張 薬や利尿薬を用いる. 未梢循環不全が強い場合 は, カテコラミン薬の静脈内投与が必要である. ECUM, CHDF, IABP, PCPS, VASなどを必 要に応じて考慮する. 呼吸管理も当然ながら重 要であり, 適切な酸素投与, NPPVさらには気管 内挿管を考慮する。

心不全治療においては, 集学的治療が必要で あるが, 内科医の立場からは, 殆どの施設で可 能である薬物療法の重要性を強調したい。薬剤 選択やさじ加減で心不全の多くはある程度改善 する，そして，慢性心不全のみならず急性心不 全においても出来るだけ臓器保護を心掛けると いう考え方が最近の治療の基盤となってきてい る. 心不全の基礎疾患や重症度でも異なるが, 内服薬としては生命予後の改善が証明されてい るACE阻害薬, $\beta$ 遮断薬, 抗アルドステロン薬が 中心となるであろう.

著者のCOI (conflicts of interest) 開示: 吉村道博; 講演料 (MSD, 協和発䣲キリン, 第一三共, ノバルティスファーマ, ファイザー, 持田製薬), 寄付金(ノバルティスファーマ,ベー リンガーインゲルハイム)

\section{文献}

1) 循環器病の診断と治療に関するガイドライン $(2010$ 年度 合同研究班報告), 急性心不全治療ガイドライン (2011 年改訂版).

2) 循環器病の診断と治療に関するガイドライン (2009 年度 合同研究班報告), 慢性心不全治療ガイドライン (2010 年改訂版).

3）川井 真：心不全と神経体液性因子との関係, 心不全の 病態と薬の使い方. 吉村道博編. 初版, 中外医学社, 213.

4) Yasue $\mathrm{H}$, et al : Localization and mechanism of secretion of B-type natriuretic peptide in comparison with those of A-type natriuretic peptide in normal subjects and patients with heart failure. Circulation 90(1) :195-203, 1994.

5) The criteria committee of the New York Heart Association : Nomenclature and criteria for diagnosis of diseases of the heart and great vessels. 9th edition, Little, Brown \& Co, Boston, Mass, 1994, 253-256.

6) Killip $\mathrm{T}$, et al : Treatment of myocardial infarction in a coronary care unit: A two year experiment with 250 patients. Am J Cardiol 20 : 457-464, 1967.

7) Forrester JS, et al : Medical therapy of acute myocardial infarction by application of hemodynamic subsets (second of two parts). N Engl J Med 295 : 1404-1413, 1976.

8) Nohria A, et al: Clinical assessment identifies hemodynamic profiles that predict outcomes in patients admitted with heart failure. J Am Coll Cardiol 41 : 1797-1804, 2003.

9) Owan TE, et al : Trends in prevalence and outcome of heart failure with preserved ejection fraction. N Engl J Med 355 : 251-259, 2006.

10) Bhatia RS, et al: Outcome of heart failure with preserved ejection fraction in a population-based study. N Engl J Med 355 : 260-269, 2006.

11) Ito $K$, et al: Serial measurements associated with an amelioration of acute heart failure : an analysis of repeated quantification of plasma BNP levels. Eur Heart J : Acute Cardiovascular Care 1 (3) : 240-247, 2012. 